${ }^{\circledR}$ Entomologica Fennica. 7 July 1998

\title{
Species richness and distribution of butterflies (Lepidoptera: Hesperioidea, Papilionoidea) in an agricultural environment in SE Finland
}

\author{
Kimmo Saarinen, Olli Marttila \& Juha Jantunen
}

\begin{abstract}
Saarinen, K., Marttila, O. \& Jantunen, J. 1998: Species richness and distribution of butterflies (Lepidoptera: Hesperioidea, Papilionoidea) in an agricultural environment in SE Finland. — Entomol. Fennica 9: 09-18.

A five-year follow-up study was carried out to assess the species richness, adult flight period and distribution of butterflies in an agricultural environment in southeastern Finland in the years 1991-1995. Butterflies were monitored once a week from early May to late September on a $2.5-\mathrm{km}$ field boundary transect. During 107 counts, a total of 49 species and 6112 individuals were observed. More than half of all individuals (56\%) were observed in July. The results of multivariate analyses indicated that the occurrence of species was related to three habitat types, classified as field margins dividing arable field and coniferous forest, arable field and deciduous forest and two arable fields. Species richness was higher in field margins near forests than in margins between two fields.
\end{abstract}

Kimmo Saarinen, Olli Martila \& Juha Jantunen, South Karelia Allergy and Environment Institute, FIN-55330 Tiuruniemi, Finland

Received 21 March 1997, accepted 21 October 1997

\section{Introduction}

The Finnish butterfly fauna consists of 114 species, of which 93 are resident (Marttila et al. 1991). In northern and central Europe the corresponding numbers are as follows: Sweden 119/109, Norway 97/92, Denmark 93/74, Estonia 111/98 and Britain 58/55 (G. Palmqvist, N. Ryrholm, L. Aarvik, P. Skou, J. Viidalepp; pers. comm.). The rather high number of species in Finland is mainly the result of a favourable geographical location. The largest part of the country belongs to the boreal climate zone, while the southwestern corner of the country is located in the hemi-boreal zone and the northernmost part is located in the hemi-arctic zone (National Board of Survey 1988, 1989).
The numbers of species in local faunas differ considerably from each other even within the same climatic zone. In southeastern Finland, at Joutseno, the annual mean of the 1980 s was 55 species, while on the southern coast, at Lohja, the mean (19581987) was 38 species (Marttila et al. 1991). In spite of accurate knowledge of regional butterfly faunas, the occurrence of butterflies in different habitats is poorly known. The ecology of butterflies and moths in mires has been studied in Finland (Väisänen 1992), but there is little knowledge concerning the occurrence and abundance of species in agricultural environments, which are known to be of major importance to the survival of butterflies (Dover et al. 1990). In Britain and central Europe, butterflies on farmland are being 
A

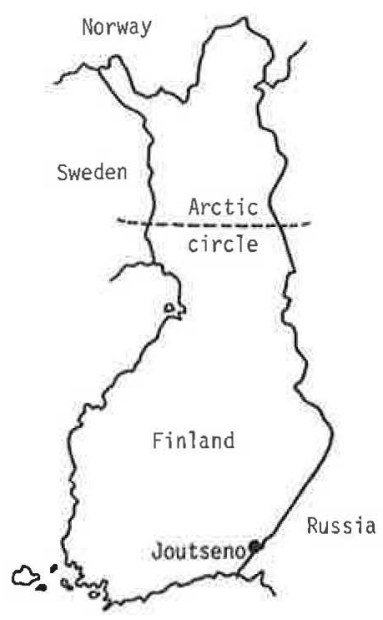

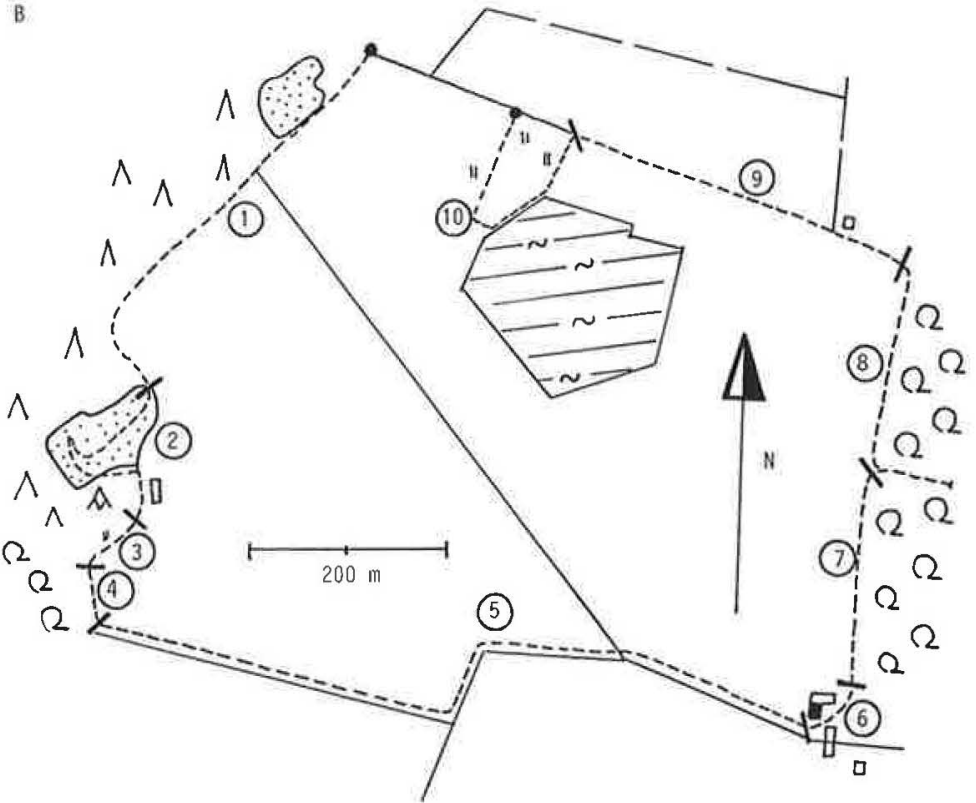

Fig. 1. (A) Location of the study area (Joutseno). (B) Transect, marked with dashed line, and the division of ten sections $(1-10)$.

well studied, usually using the transect count method first described by Pollard et al. (1975). Work has been focused, for example, on an examination of the effects of reduced pesticide use (Rands \& Sotherton 1986), butterfly movement and activity (Dover et al. 1992), population size estimations (Nagel et al. 1991) and the effects of environmental changes or the management of field margins (Robertson et al. 1988, Feber et al. 1994, Kitahara \& Fujii 1994). The basis of the method is presented in detail by Pollard and Yates (1993). The general use of transect counts has also provided a good background for comparisons of butterfly abundances between different regions.

The objective of the present study was to determine the butterfly species richness, the adult flight period and the distribution of species in different agricultural habitats by using field boundary transect counts.

\section{Material and methods}

The study was carried out at Joutseno $\left(61^{\circ} 10^{\prime} \mathrm{N}, 28^{\circ} 41^{\prime} \mathrm{E}\right)$, in the southern boreal climate zone. The temperature represented by monthly averages (1961-1990) ranges from $+16.7^{\circ} \mathrm{C}$ in July to $-9.4^{\circ} \mathrm{C}$ in January. The snow cover lasts from early December to mid-April. The study area, situated in the countryside some $5 \mathrm{~km}$ from the town of Imatra, was characterized by fields of cereals, hay and forage plants, although the vegetation in the region consists mainly of coniferous forests typical of the boreal zone. The transect was situated at the edges of open arable land, which was surrounded by young coniferous and deciduous forests. The total length of a $2530-\mathrm{m}$ field boundary transect was originally divided into 10 sections, which coincide with changes in the nature of the habitat being recorded (Fig. 1, Table 1).

The Pollard transect count method was used between 1991 and 1995. All individuals seen in front of the observer at a range of $5 \mathrm{~m}$ or less were counted by sections. For identification, some individuals were captured with an insect net and were afterwards released. The duration of one census varied from 45 to 120 minutes depending on the abundance of butterflies. The transect counts were conducted once a week from early May to the end of September. The number of annual censuses was 20 (1991, 1992), 22 (1993, 1994) and 23 (1995), totalling 107 counts. Due to unfavourable weather conditions, butterflies could not be censused in weeks 22 (1991), 34 (1992, 1993) and 37 (1994).

Counts were started in the early afternoon (mean 13.20, range 10.30-15.30) in the best possible weather conditions. Data on temperature, windspeed and sunshine percentage collected at the time of each census is given in Table 2 . The temperature was measured at one point in Section 1 and windspeed was estimated by a single number on a scale of 1 (calm) to 6 (strong wind) after each census. The average sunshine percentage, estimated by sections with structured alternatives 0 (= completely overcast), 25, 50, 75 and $100 \%$ (= clear sky), was calculated after each count. 
In further analysis, 10 sections of the transect were combined into three categories. These section groups were formed with the multivariate method by the CANOCO program, using the Canonical Correspondence Analysis (CCA) (ter Braak 1987). Environmental factors for each section were estimated by a single number on a scale of 1 to 5 . The factors were as follows: the age of the tree stand indicating the stability (STABILIT in Fig. 2), the quality of the tree stand expressed by the proportion of coniferous trees (CONIFERS), the combination of the field layer flora indicated by the relative abundances of grove species (GROVESPE), heath species (HEATHSPE) and weed species (WEEDSPE), the ground moisture (MOISTURE) and the degree of wind (WIND) and shading (SHADING). The CCA ordination was carried out by using the data of 8 environmental variables and 34 butterfly species (observed $\geq 10$ individuals along the transect during the five-year period). The ordination diagrams illustrate the species and sections in relation to environmental factors marked with arrows. Arrow lengths give an idea of the significance of the environmental variables presented. The arrow points roughly in the direction of maximum variation in the value of the corresponding variable. The diagram illustrates the division of sections into three groups (Fig. 2):

Group I. Sections 1, 2, 3 and 4 (a total of $700 \mathrm{~m}$ ) represented the field margins lined with arable fields in the east and dry heath with large Scots pines (Pinus sylvestris) and few deciduous trees and shrubs in the west. The most abun- dant plant species of the field layer were Arctostaphylos uva-ursi, Calluna vulgaris, Deschampsia flexuosa, Festuca ovina and Vaccinium myrtillus. Plants adapted to dry and nutrient-poor habitats such as Fragaria vesca, Knautia arvensis, Pilosella officinarum and Trifolium aureum appeared in small numbers, but were absent in other groups. Owing to the mature pine trees lining the sections, environmental conditions were fairly stable within this group.

Group II. Sections 6, 7 and 8 (a total of $510 \mathrm{~m}$ ) represented the field margins lined with arable fields in the west and young and luxuriant deciduous forests with aspen ( $P$ opulus tremula) as the main species in the east. The vegetation of the field layer mainly consisted of Convallaria majalis, Deschampsia cespitosa, Filipendula ulmaria, Galium. boreale, Geranium sylvaticum and Succisa pratensis. Grove species such as Daphne mezereum, Hepatica nobilis and Pulmonaria obscura, as well as species adapted to wet conditions, for example Geranium palustre, Potentilla palustris and Viola palustris, were common. Due to the fairly young trees and the strong succession of vegetation at the forest boundary, environmental conditions were unstable within this group.

Group III. Sections 5, 9 and 10 (a total of $1320 \mathrm{~m}$ ) represented the field margins in the middle of arable land without lining forests. Cultivated plants varied from year to year from turnip rape, rye, oat and wheat to different forage plants. The vegetation of the field layer included weeds and other species, such as Cirsium arvense, Elymus repens, Epilobium angustifolium, Tussilago farfara and Urtica dioica,

Table 1.10 sections of the transect.

Section Environment

Length

1. Half-open area between dry heath and field

$430 \mathrm{~m}$

2. Bushy and half-open area around old gravel pit

$180 \mathrm{~m}$

3. Meadow-like half-open area between mixed forest and field

$30 \mathrm{~m}$

$60 \mathrm{~m}$

4. Half-open area between mixed forest and field

5. Open area between two fields; some bushes here and there

$760 \mathrm{~m}$

6. Half-open courtyard of an old house

$40 \mathrm{~m}$

7. Half-open area between moist aspen forest and field

$200 \mathrm{~m}$

8. First half-open part is meadow-like area rounded by moist deciduous forest, the end is similar to section 7

$270 \mathrm{~m}$

$360 \mathrm{~m}$

9. Bushy open area between two fields

$200 \mathrm{~m}$

10. Bushy open waste land

$2530 \mathrm{~m}$

Total

Table 2. The annual weather data collected during the censuses.

\begin{tabular}{|c|c|c|c|c|c|c|c|c|c|c|}
\hline & \multicolumn{2}{|c|}{$\begin{array}{c}1991 \\
n=20\end{array}$} & \multicolumn{2}{|c|}{$\begin{array}{c}1992 \\
n=20\end{array}$} & \multicolumn{2}{|c|}{$\begin{array}{c}1993 \\
n=22\end{array}$} & \multicolumn{2}{|c|}{$\begin{array}{c}1994 \\
n=22\end{array}$} & \multicolumn{2}{|c|}{$\begin{array}{c}1995 \\
n=23\end{array}$} \\
\hline & Mean & SD & Mean & $\mathrm{SD}$ & Mean & SD & Mean & SD & Mean & SD \\
\hline Temperature $\left({ }^{\circ} \mathrm{C}\right)$ & 18.8 & 4.6 & 18.8 & 2.8 & 16.7 & 4.3 & 18.3 & 4.0 & 19.5 & 5.4 \\
\hline Windspeed (1-6) & 2.6 & 1.2 & 2.8 & 1.2 & 2.0 & 0.8 & 2.4 & 1.1 & 2.4 & 0.8 \\
\hline Degree of sunshine (\%) & 78.8 & 26.1 & 87.5 & 18.0 & 77.1 & 29.3 & 90.4 & 13.5 & 92.9 & 9.0 \\
\hline
\end{tabular}



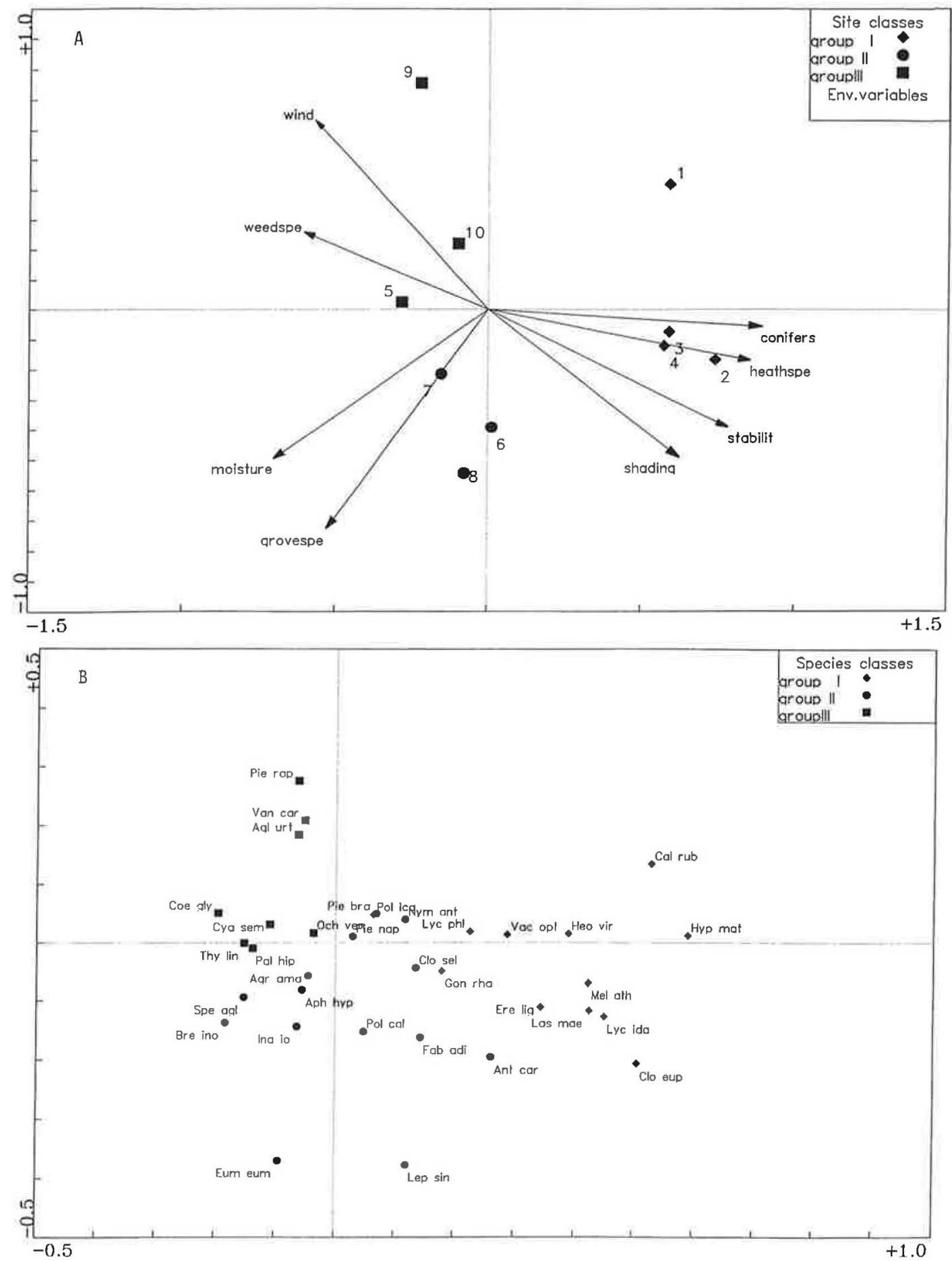

Fig. 2. CCA-ordination diagrams of butterflies and sections, with respect to 8 different environmental variables presented with arrows (see Methods). Eigenvalues are 0.230 for axis 1 and 0.091 for axis 2. (A) Environmental variables and sections. = Group I (Sections 1-4), $9=$ Group II (Sections 6-8), $\mathbf{0}=$ Group III (Sections 5, 9 and 10). (B) Butterfly species observed more than 10 individuals during the five-year period (see full names in Table 3). = species of group I, - = species of group II, 嘈 = species of group III. 
adapted to high nutrient levels. Owing to strong variation in the vegetation and a freely blowing wind with no shading trees, environmental conditions were highly unstable within this group.

The number of species (species richness) in three section groups was evaluated with rarefaction, which is a statistical method of estimating the number of species expected in a random sample of individuals taken from a census. Given the number of individuals in each species for the census, one can calculate how many species would be expected in a smaller sample of $n$ individuals (James \& Rathbun 1981). In our analysis we used a sample size of 250 individuals in each section group. In order to avoid a bias introduced by the different size of the area, in this case the length of the group, the numbers of individuals of each species were reduced to the number expected on 500 metres in each section group. When the numbers of species expected in samples of this size were calculated by rarefaction, the communities could be compared.

Habitat preferences of butterflies were studied by using relative abundances of each species in three section groups. Relative abundances were calculated by using the length of the longest section group (III: $1320 \mathrm{~m}$ ), the coefficients being 1.9 in Group I $(1.9 \times 700 \mathrm{~m}=1320 \mathrm{~m})$ and 2.6 in Group II. For example, the numbers of Ochlodes venatus in three groups were 24 (I), 27 (II) and 73 (III). The relative abundances were consequently 46 in Group I ( $24 \times$ $1.9=46), 70$ in Group II and 73 in Group III, the total relative number being 189 individuals. The proportion of $O$. venatus was thus $24 \%$ in Group I $(46 / 189=0.24), 37 \%$ in Group II and 39\% in Group III.

\section{Results}

During the five-year period (1991-1995), a total of 49 species and 6112 individuals were observed (Table 3). The annual number of species and individuals varied from 35 (1994) to 42 (1992) and from 858 (1993) to 1912 (1995), respectively. Altogether 23 species were observed annually, the proportion of the five most abundant species, Thymelicus lineola, Pieris napi, Aphantopus hyperantus, Aglais urticae and Gonepteryx rhamni constituting more than two thirds $(69 \%)$ of all the individuals. Less than 10 individuals were observed for 15 species.

The greatest numbers of species and individuals were observed during the high summer, especially in July. Altogether 56\% of all individuals were counted during the six-week period between late June and early August. The peak of the species and individual numbers was attained, on average, during weeks 28 and 30 (Fig. 3).
The numbers of species and individuals observed in three section groups were 44 and 1432 (I), 40 and 1614 (II) and 41 and 3066 (III), respectively. By rarefaction, the numbers of species expected in the sample of 250 individuals were 30.7 in Group I, 26.0 in Group II and 23.4 in Group III. The relative abundances of 34 species (observed $\geq 10$ individuals during the study period), when classified by their highest proportion in three section groups, indicated habitat preferences of butterfly species in agricultural environments (Table 4).

\section{Discussion}

\subsection{Validity of results}

The transect method has considerable potential for assessing the species richness of butterflies (Pollard 1991, Pollard \& Yates 1993). Although there was only one transect site, the butterfly data consisted of almost all the resident species living in the region. Due to the resemblance of the results of the present study to the data from the first two years (Marttila \& Klemetti 1993), it was assumed that the study period was long enough to provide the basic data of species richness, adult flight periods and habitat preferences of butterflies.

Line transects are usually divided into sections, which simplify counting and also enable some assessment to be made of the occurrence of butterflies in different habitats (Pollard 1977). In the present study the transect was originally divided into 10 sections, but due to the resemblance of some sections, they were combined into three groups. The canonical correspondence analysis (CCA) supported the division and made it possible to compare habitat preferences of butterflies between section groups.

Censuses were conducted by six amateur and professional entomologists. A study by Pollard (1977) indicated that different recorders show similar trends in counts. Almost all the species were easily recognizable by an experienced observer in the field. Unidentified individuals were not included in the data. The number of inactive and small species may also be underestimated, but the effect is similar in different habitat groups.

Regular counts at one-week intervals made the butterfly data representative. All the censuses were 
Table 3. Species and individuals along the transect in 1991-1995. Species observed in all years are marked with $\left(^{*}\right)$.

\begin{tabular}{|c|c|c|c|c|c|c|c|}
\hline \multicolumn{2}{|c|}{ Species } & \multirow{2}{*}{$\begin{array}{r}1991 \\
3\end{array}$} & \multirow{2}{*}{$\begin{array}{r}1992 \\
1\end{array}$} & \multirow{2}{*}{$\begin{array}{r}1993 \\
1\end{array}$} & \multirow{2}{*}{$\begin{array}{r}1994 \\
0\end{array}$} & \multirow{2}{*}{$\begin{array}{r}1995 \\
0\end{array}$} & \multirow{2}{*}{ Total } \\
\hline 1. & Pyrgus malvae (L.) & & & & & & \\
\hline 2. & Carterocephalus silvicola (Meig.) & 1 & 1 & 1 & 0 & 0 & 3 \\
\hline 3. & * Thymelicus lineola (Och.) & 212 & 183 & 71 & 127 & 457 & 1050 \\
\hline 4. & * Ochlodes venatus (Br. \& Gr.) & 31 & 63 & 6 & 1 & 23 & 124 \\
\hline 5. & Papilio machaon (L.) & 0 & 0 & 1 & 0 & 0 & 1 \\
\hline 6. & Leptidea sinapis (L.) & 0 & 1 & 10 & 3 & 4 & 18 \\
\hline 7. & Aporia crataegi (L.) & 1 & 4 & 0 & 1 & 1 & 7 \\
\hline 8. & Pieris brassicae (L.) & 0 & 8 & 1 & 2 & 21 & 32 \\
\hline 9. & Pieris rapae (L.) & 0 & 110 & 12 & 10 & 21 & 153 \\
\hline 10. & * Pieris napi (L.) & 36 & 152 & 223 & 374 & 215 & 1000 \\
\hline 11. & Anthocharis cardamines (L.) & 2 & 3 & 3 & 2 & 0 & 10 \\
\hline 12. & Colias palaeno (L.) & 0 & 0 & 0 & 0 & 1 & 1 \\
\hline 13. & * Gonepteryx rhamni (L.) & 109 & 174 & 55 & 44 & 144 & 526 \\
\hline 14. & Thecla betulae (L.) & 1 & 0 & 3 & 0 & 0 & 4 \\
\hline 15. & Fixsenia pruni (L.) & 1 & 0 & 0 & 0 & 0 & 1 \\
\hline 16. & * Callophrys rubi (L.) & 16 & 12 & 75 & 24 & 50 & 177 \\
\hline 17. & * Lycaena phlaeas (L.) & 4 & 10 & 1 & 5 & 5 & 25 \\
\hline 18. & * Heodes virgaureae (L.) & 11 & 18 & 1 & 4 & 11 & 45 \\
\hline 19. & Palaeochrysophanus hippothoe (L.) & 2 & 4 & 0 & 0 & 5 & 11 \\
\hline 20. & Celastrina argiolus (L.) & 0 & 0 & 2 & 1 & 0 & 3 \\
\hline 21. & Glaucopsyche alexis (Poda) & 0 & 1 & 0 & 0 & 1 & 2 \\
\hline 22. & Plebejus argus (L.) & 0 & 0 & 1 & 2 & 0 & 3 \\
\hline 23. & Lycaeides idas (L.) & 0 & 4 & 1 & 1 & 3 & 19 \\
\hline 24. & Aricia artaxerxes (Fabr.) & 1 & 2 & 0 & 0 & 1 & 4 \\
\hline 25. & * Eumedonia eumedon (Esper) & 3 & 5 & 5 & 4 & 9 & 26 \\
\hline 26. & Vacciniina optilete (Knoch) & 3 & 6 & 4 & 0 & 1 & 14 \\
\hline 27. & * Cyaniris semiargus (Rott.) & 5 & 34 & 7 & 5 & 14 & 65 \\
\hline 28. & * Agrodiaetus amandus (Schn.) & 18 & 83 & 31 & 7 & 67 & 206 \\
\hline 29. & * Polyommatus icarus (Rott.) & 3 & 8 & 3 & 4 & 2 & 20 \\
\hline 30. & Limenitis populi (L.) & 0 & 2 & 0 & 0 & 3 & 5 \\
\hline 31. & * Nymphalis antiopa (L.) & 1 & 12 & 4 & 1 & 1 & 19 \\
\hline 32. & * Inachis io (L.) & 17 & 6 & 7 & 1 & 8 & 39 \\
\hline 33. & Vanessa atalanta (L.) & 1 & 1 & 0 & 2 & 2 & 6 \\
\hline 34. & Vanessa cardui (L.) & 1 & 0 & 0 & 0 & 10 & 11 \\
\hline 35. & * Aglais urticae (L.) & 104 & 36 & 73 & 305 & 258 & 776 \\
\hline 36. & * Polygonia c-album (L.) & 5 & 16 & 19 & 4 & 9 & 53 \\
\hline 37. & * Speyeria aglaja (L.) & 6 & 4 & 7 & 5 & 14 & 36 \\
\hline 38. & Fabriciana niobe (L.) & 0 & 1 & 1 & 0 & 1 & 3 \\
\hline 39. & Fabriciana adippe (D. \& S.) & 0 & 4 & 5 & 16 & 14 & 39 \\
\hline 40. & * Brenthis ino (Rott.) & 30 & 54 & 36 & 57 & 230 & 407 \\
\hline 41. & * Clossiana selene (D. \& S.) & 3 & 13 & 6 & 6 & 13 & 41 \\
\hline 42. & Clossiana euphrosyne (L.) & 1 & 3 & 7 & 1 & 0 & 12 \\
\hline 43. & Mellicta athalia (Rott.) & 3 & 3 & 0 & 0 & 5 & 11 \\
\hline 44. & * Hypodryas maturna (L.) & 11 & 7 & 18 & 4 & 1 & 41 \\
\hline 45. & * Erebia ligea (L.) & 9 & 9 & 35 & 6 & 44 & 103 \\
\hline 46. & * Aphantopus hyperantus (L.) & 277 & 199 & 108 & 54 & 209 & 847 \\
\hline 47. & Coenonympha pamphilus (L.) & 1 & 2 & 3 & 1 & 0 & 7 \\
\hline 48. & * Coenonympha glycerion (Brkh.) & 6 & 4 & 2 & 1 & 8 & 21 \\
\hline 49. & * Lasiommata maera (L.) & 13 & 34 & 9 & 8 & 16 & 80 \\
\hline \multirow{2}{*}{\multicolumn{2}{|c|}{$\begin{array}{l}\text { Species } \\
\text { Individuals }\end{array}$}} & 37 & 42 & 39 & 35 & 39 & 49 \\
\hline & & 952 & 1297 & 858 & 1093 & 1912 & 6112 \\
\hline
\end{tabular}



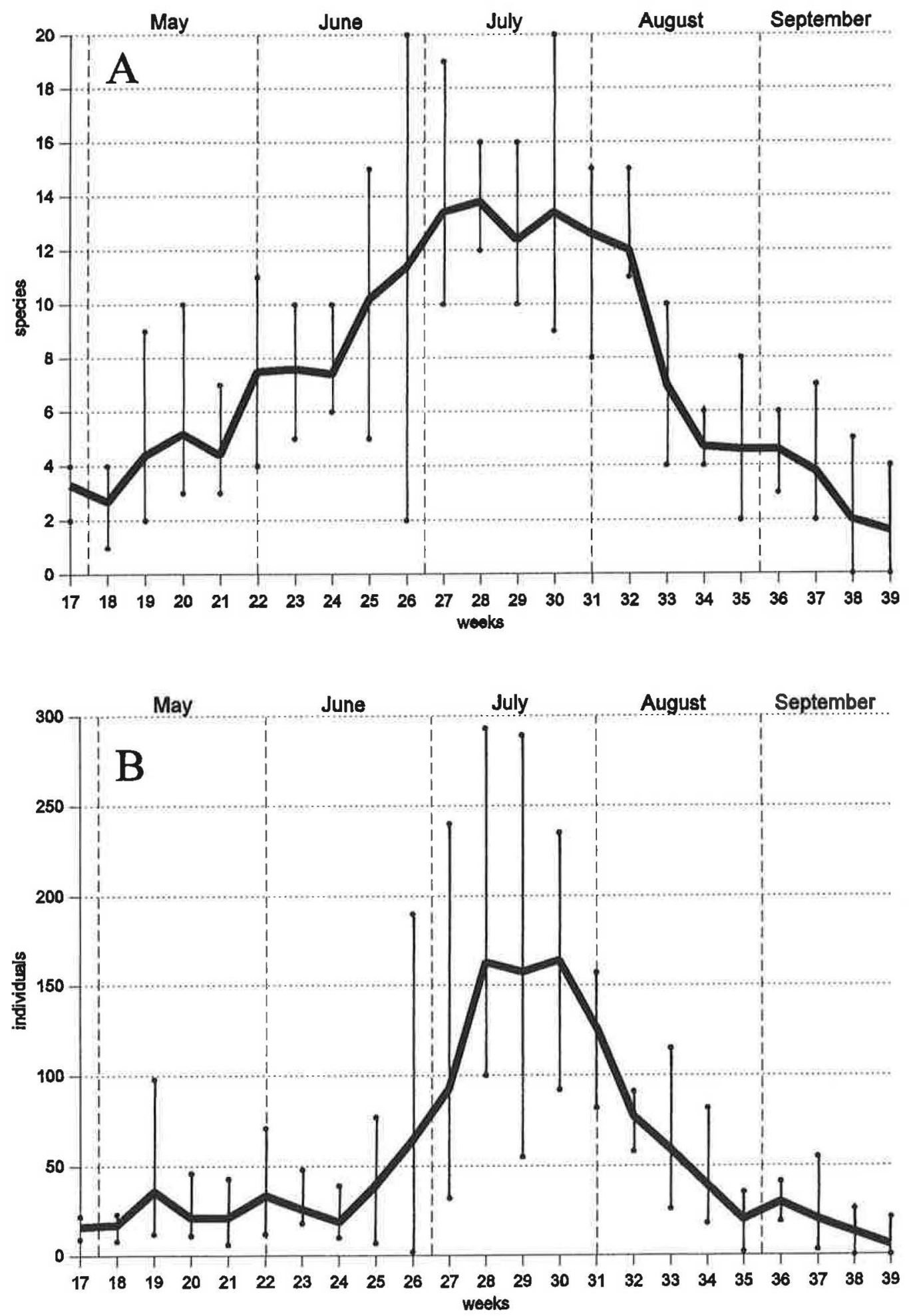

Fig. 3. The average and range of butterfly species (A) and individuals $(B)$ observed by transect in the course of the summer. 
conducted in good or satisfactory weather conditions in the early afternoon, coinciding with the day's maximum density of butterflies (Moore 1975). In addition, data collected by Pollard (1977) indicated that small variations in weather conditions within the recommended limits are not of any great importance.

\subsection{Species richness and adult flight period}

Farmland is considered to support a relatively impoverished butterfly fauna with a restricted occurrence along field boundaries and in other noncultivated areas. The field margins are often the only suitable habitats in an arable landscape for woodland and grassland butterfly species (Sparks $\&$ Parish 1995). During the five-year period, $43 \%$ of all and $52 \%$ of resident species in Finland were discovered in an agricultural environment at Joutseno with a field boundary transect. Only five resident species known to live in the region (Pyrgus alveus, Argynnis paphia, Issoria lathonia, Eurodryas aurinia and Lasiommata petropolitana) were not observed along the transect.

The results of the present study indicate great species richness. This supported the earlier ob- servations from the same municipality. The annual mean of butterfly species at Joutseno was greater than on the southern coast at Lohja (Marttila et al. 1991). Marttila (1992) noticed that the richness of nocturnal Lepidoptera was also higher in southeastern Finland compared with the other parts of southern Finland. He suggested two explanations: 1) the fauna living in the area consists of both Mediterranean and Siberian elements, and 2) the continental climate, with its warm summer and thick snow cover in winter, provides good conditions for reproduction (Price 1975).

Butterflies of an agricultural environment have been studied with transects in particular in Britain. Dozens of studies accomplished with different time periods and numbers of transects have resulted in 18-29 species observed with the transect (Moore 1975, Rands \& Sotherton 1986, Dover et al. 1990, Williams et al. 1991, Munguira \& Thomas 1992). Although the butterfly diversity in southeastern Finland is higher than in Britain, the proportion of the resident species observed in one site is of the same magnitude (30-50\%).

More than half of all individuals were observed in July and the number of species was at its highest at the same time. These observations are in accordance with data on butterflies collected occa-

Table 4. Division of 34 butterfly species (more than 10 individuals observed) in three section groups, based on the relative abundances of the species. Butterflies are classified by their highest proportion in three habitat groups.

\section{Group 1}

(Sections 1-4)

Dry and stable habitat between field and coniferous forest

Species \%

\section{H. maturna}

C. rubi

L. idas

H. virgaureae

C. euphrosyne

L. phlaeas

L. maera

V. optilete

M. athalia

E. ligea

G. rhamni

$P$. icarus

\section{Group II \\ (Sections 6-8)}

Moist and luxuriant habitat between field and deciduous forest

Species $\%$

\section{E. eumedon}

L. sinapis

I. io

$B$. ino

P. c-album

A. cardamines

S. aglaja

C. selene

A. hyperantus

A. amandus

F. adippe

P. napi

N. antiopa

$P$. brassicae
Group III

(Sections 5, $9 \& 10$ )

Modest environment between two arable fields

\begin{tabular}{ll} 
Species & $\%$ \\
\hline C. glycerion & 81 \\
P. hippothoe & 67 \\
C. semiargus & 54 \\
A. urticae & 52 \\
T. lineola & 49 \\
P. rapae & 46 \\
V. cardui & 44 \\
O. venatus & 39
\end{tabular}


sionally with variable methods in coastal areas in southern Finland during a 22-year period (19471968). The peak of more than 35000 individuals was attained in late July (Ekholm 1975). A strong concentration of adult flight periods is simply the result of adaptation to a short summer with the best possible conditions for reproduction.

\subsection{Habitat preference of butterflies}

The environmental variables supported the division of sections into three categories of field margins: those that divided fields and different types of forests (Groups I and II) and those between two arable fields (Group III). These groups were regarded as the main habitat types. By using these groups instead of 10 sections, the chance of the species occurring in the "wrong" habitat was decreased. This could have resulted, for example, from the location of few nectar sources (Frazer 1973, Yamamoto 1975, Pollard 1977).

The models presented by Sparks and Parish (1995) clearly show that butterfly populations in agricultural environments are strongly affected by the floral composition and structure of the hedgerow. In the present study we paid attention to other environmental variables as well. The relative abundances of the species in relation to environmental factors of the habitat groups confirmed the earlier suppositions of the habitat preferences of butterflies (Martila et al. 1991). For example, the distribution of Callophrys rubi, Hypodryas maturna and Lycaeides idas was emphasized in section Group I of a slightly dry, stable and semiopen environment. Species observed mostly in Group II included Eumedonia eumedon, Leptidea sinapis, Brenthis ino, Anthocharis cardamines and many scarce species (observed $<10$ individuals, thus excluded from the analysis) such as Limenitis populi, Thecla betulae and Glaucopsyche alexis, all indicating the preference of moist and luxuriant young habitats. Coenonympha glycerion, Cyaniris semiargus, Aglais urticae and Pieris rapae, which were observed mostly within Group III, are typical of environments under continuous change. The majority of southern migrants, known to be eurytopic species, were also seen within sections of Group III.

It is generally accepted that unstable and unpredictable environments with frequent distur- bances result in lower species diversity than stable and predictable ones (Kitahara \& Fujii 1994). This was also the case in three habitat groups. When the habitats and number of individuals were equalized with rarefaction, species richness appeared to be higher in field margins near forests (Groups I and II) compared with margins between two fields (Group III). Butterfly populations in the middle of arable land may be reduced directly through contact with agricultural sprays or spray drift, or indirectly through the reduced floral diversity following herbicide use leading to a reduction in nectar sources or larval foodplants (Sparks \& Parish 1995).

The field boundaries are very important to butterflies, not only as breeding sites, but also as vital links between different habitats (Dover et al. 1992). This probably affected the appearance of some species. Pieris napi, Nymphalis antiopa and Pieris brassicae were concentrated in section Group II, although this kind of environment is not supposed to be preferred by these species. The explanation might be that they all form open populations and the species fly in all kinds of habitats with quite similar intensities, possibly using the field boundaries as movement channels. This was supported by their having the lowest proportions $(47 \%, 45 \%$ and $39 \%$, respectively) of all species in Group II.

Knowledge of habitat preferences of butterflies on arable land is especially needed when conservation acts are being planned. There are 26 threatened butterfly species in Finland, most of them adapted to open and semiopen agricultural environments (Marttila et al. 1991, Rassi et al. 1992). The survival of several endangered species can be ensured only through the more effective conservation of habitats in the wider countryside or through habitat management. The role of the latter has continuously increased, but only a few projects have been accomplished in Finland so far (e.g. Seuranen 1996, Sihvonen 1996, Sundell 1996). It is evident that the small amount of habitat managements conducted is at least partially due to the insufficient knowledge concerning the ecological demands of the species living in the agricultural environments.

We conclude that the field margins in an agricultural environment can support a large variety of butterfly species, which are adapted to different types of margins. The occurrence of species 
and flight periods are strongly concentrated in July due to the short and intensive summer typical of the southern boreal zone.

Acknowledgements. We thank Pekka Marttila, Teemu Klemetti and Hannu Aarnio for their assistance in the field work and Sanna Saarnio for helping in statistics. Also, Dr. Rauno Väisänen and Leigh Plester for reading and commenting on the manuscript. We are indebted to Leif Aarvik (Norway), Göran Palmqvist and Nils Ryrholm (Sweden), Peder Skou (Denmark) and Jaan Viidalepp (Estonia) for information about the butterfly faunas in adjacent countries.

\section{References}

Dover, J. W., Sotherton, N. W. \& Gobbett, K. 1990: Reduced pesticide inputs on cereal field margins: the effects on butterfly abundance. - Ecol. Entomol. 15: 17-24.

Dover, J. W., Clarke, S. A. \& Rew, L. 1992: Habitats and movement patterns of satyrid butterflies (Lepidoptera: Satyridae) on arable farmland. - Entomol. Gaz. 43: 29-44.

Ekholm, S. 1975: Fluctuations in butterfly frequency in Central Nyland. - Not. Entomol. 55: 65-80.

Feber, R. E., Smith, H. \& MacDonald, D. W. 1994: The effects of field margin restoration on the meadow brown butterfly (Maniola jurtina). — In: Boatman, N. D. (ed.), Field margins: integrating agriculture and conservation: 295-300. BCPC Monogr. No. 58, Farnborough. 404 pp.

Frazer, J. F. D. 1973: Estimating butterfly numbers. - Biol. Conserv. 5: 271-276.

James, F. C. \& Rathbun, S. 1981: Rarefaction, relative abundance, and diversity of Avian communities. - Auk 98: 785-800.

Kitahara, M. \& Fujii, K. 1994: Biodiversity and community structure of temperate butterfly species within a gradient of human disturbance: An analysis based on the concept of generalist vs. specialist strategies. Res. Popul. Ecol. 36: 187-199.

Marttila, O. 1992: Yöperhosten (Lepidoptera: Drepanoidea, Geometroidea, Bombycoidea, Sphingoidea, Noctuoidea) lennon ajoittuminen ja yhteys tehoisaan lämpösummaan. - South Karelia Allergy and Environment Institute, Joutseno. 49 pp.

Marttila, O. \& Klemetti, T. 1993: Päiväperhosten linjaarviointi Joutsenossa vuosina 1991 ja 1992. — Baptria 18: 43-50.

Marttila, O., Haahtela, T., Aamio, H. \& Ojalainen, P. 1991 : Suomen päiväperhoset, 2nd ed. — Kirjayhtymä, Helsinki. 370 pp.

Moore, N. W. 1975: Butterfly transect in a linear habitat 1964-1973. - Entomol. Gaz. 26: 71-78.

Munguira, M. L. \& Thomas, J. A. 1992: Use of road verges by butterfly and burnet populations, and the effect of roads on adult dispersal and mortality. - J. Appl. Ecol. 29: 316-329.
Nagel, H. G., Nightengale, T. \& Dankert, N. 1991: Regal fritillary butterfly population estimation and natural history on Rowe Sanctuary, Nebraska. - Prairie Nat. 23: 145-152.

National Board of Survey 1988: Suomen kartasto 131, ilmasto. - Suomen maantieteellinen seura, Helsinki. $31 \mathrm{pp}$.

National Board of Survey 1989: Suomen kartasto 141-143, elävä luonto, luonnonsuojelu. — Suomen maantieteellinen seura, Helsinki. 32 pp.

Pollard, E. 1977: A method of assessing changes in the abundance of butterflies. - Biol. Conserv. 12: 115-134.

Pollard, E. 1991: Synchrony of population fluctuations: the dominant influence of widespread factors on local butterfly populations. - Oikos 60: 7-10.

Pollard, E. \& Yates, T. J. 1993: Monitoring butterflies for ecology and conservation. The British butterfly monitoring scheme. - Chapman \& Hall, London. 274 pp.

Pollard, E., Elias, D. O., Skelton, M. J. \& Thomas, J. A. 1975: A method of assessing the abundance of butterflies in Monks Wood National Reserve in 1973. —Entomol. Gaz. 26: 79-88.

Price, P. W. 1975: Insect ecology, — John Wiley \& Sons, New York. 514 pp.

Rands, M. R. W. \& Sotherton, N. W. 1986: Pesticide use on cereal crops and changes in the abundance of butterflies on arable farmland in England. - Biol. Conserv. 36: 71-82.

Rassi, P., Kaipainen, H., Mannerkoski, I. \& Ståhls, G. (eds.) 1992: Uhanalaisten eläinten ja kasvien seurantatoimikunnan mietintö (Report on the monitoring of threatened animals and plants in Finland). - Komiteanmietintö 1991: 30. Ympäristöministeriö, Helsinki. 328 pp.

Robertson, P. A., Woodburn, M. I. A. \& Hill, D. A. 1988: The effects of woodland management for pheasants on the abundance of butterflies in Dorset, England. - Biol. Conserv. 45: 159-167.

Seuranen, I. 1996. Tummaverkkoperhosen elinympäristön hoitotalkoot Orivedellä 1996. — Baptria 21: 142-143.

Sihvonen, P. 1996: Kalliosinisiiven elinympäristön kunnostus Savonlinnassa. - Baptria 21: 147-149.

Sparks, T. H. \& Parish, T. 1995: Factors affecting the abundance of butterflies in field boundaries in Swavesey fens, Cambridgeshire, UK. - Biol. Conserv. 73: 221-227.

Sundell, P. R. 1996: Pikkusinisiipitalkoot Heinolassa 25.26.5. \& 7.9.1996. - Baptria 21: 141-142.

ter Braak, C. J. F. 1987: CANOCO - a FORTRAN program for canonical community ordination by partial detrended canonical correspondence analysis, principal components analysis and redundancy analysis. TNO Inst. Appl. Computer Sci, Wageningen. 95 pp.

Väisänen, R. 1992: Distribution and abundance of diurnal Lepidoptera on a raised bog in southem Finland. Ann. Zool. Fennici 29: 75-92.

Williams, L. R., Kwissa, A., Brown, D. \& Brown, J. 1991: Butterfly monitoring at Fryent Country Park, Middlesex, 1986-90. — Lond. Nat. 70: 73-80.

Yamamoto, M. 1975: Notes of the methods of belt transect census of butterflies. - J. Fac. Sci. Hokkaido Univ., Zoology 20: 93-116. 